\title{
Processing and Utilization of Satavari Roots for Preparation of Herbal Aonla Ladoo
}

\author{
Jyoti Prabha Bishnoi $^{1 *}$, Rakesh Gehlot ${ }^{2}$, S. Siddiqui ${ }^{2}$ and Isha Kaushik ${ }^{2}$ \\ ${ }^{1}$ Amity institute of Biotechnology, Amity University Rajasthan, Jaipur-303002, \\ Rajasthan, India \\ ${ }^{2}$ Centre of Food Science and Technology, CCS Haryana Agricultural University, \\ Hisar-125 004, Haryana, India \\ *Corresponding author
}

\begin{abstract}
A B S T R A C T
Satavari is known as queen of herbs. Active chemical constituents of Shatavari are

Keywords

Herbal, Satavari, Aonla, Chakaiya, Ladoo, Sensory characteristics

\section{Article Info}

Accepted:

24 February 2018

Available Online:

10 March 2018

Sarsapogenin, Saponins A-4 to A-7, Shatavarin I to IV, Sitosterol, Glycosides of quercetin, Stigmasterol, Asparagamine A and Sitosterol 7. High temperature during processing has no effect on these active constituents. Hence attempt was made to utilize satavari roots powder for preparation of herbal aonla ladoo. Satavari roots were processed to prepare powder and herbal aonla ladoo using satavari powder $(2,4$ and $6 \%$ ) were developed and evaluated. On the basis of sensory analysis, herbal aonla ladoo using satavari powder (4\%) was found most acceptable. The freshly prepared herbal aonla ladoo containing satavari powder was analyzed for various chemical characteristics. The moisture content $(35.3 \%)$, total soluble solids $(63.3 \%)$, total sugars $(52.7 \%)$, reducing sugars $(28.2 \%)$, titratable acidity $(1.46 \%)$, ascorbic acid $(257 \mathrm{mg} / 100 \mathrm{~g})$, pectin $(0.43 \%)$, total phenols $(1.99 \mathrm{mg} / \mathrm{g})$ and non-enzymatic browning $(0.13)$ were recorded for herbal aonla ladoo containing satavari powder (4\%).Thus, present study was first in its kind to determine overall acceptability, chemical composition and effect of storage period on chemical constituents of herbal aonla ladoo obtained from aonla fruits cv. Chakaiyaand satavari root powder.
\end{abstract}

\section{Introduction}

Aonla (Phyllanthus emblica L.) is one of the oldest Indian fruits and considered as "Wonder fruit for health". The fresh fruits are not popular as a table fruit due to its high acidity and astringent taste (Kumar and Nath, 1993). Further, aonla, being perishable, loses its nutritional value in absence of proper postharvest technology; therefore, it is not popular as a table fruit, but has a great potential in processed forms. Several value added products have been developed from aonla such as pickles, preserve (murrabba), candy, sauce, chutney, jam, jelly, spread and ladoo. Aonla ladoo is prepared from aonla shreds. It is ballshaped, exceedingly sweet, highly flavourful and easily masticated product. Expanding knowledge of the role of physiologically active food components, from both plant (phytochemicals) and animal (zoo-chemicals) sources, has notably changed the role of diet 
in health. This has led to the development of a new generation of foods termed functional foods. Functional foods are generally described as foods and beverages that provide health benefits beyond their inherent nutritional value. Increased consumer interest in improving overall health and reducing risk for specific diseases has fuelled the demand for foods that provide health benefits beyond their traditional nutritional value (i.e., socalled functional foods).Nutritional and medicinal qualities of ladoo can be enriched by addition of ingredients such as medicinal plant extract or powder (Reddy et al., 2005). Herbal inclusion not only gives medicinal qualities but can also give new flavor to the product.

Satavari (Asparagus racemosus) is an indigenous medicinal plant of the family Liliaceae. It is commonly known as Satavar or Satamuli in Hindi and is a perennial climbing shrub with fleshy roots. Satavari is known as queen of herbs, mainly used in Ayurveda and Unani systems of medicine. Species of Shatavari are found throughout India especially in northern India. Chemical constituents of Shatavari are Sarsapogenin, Saponins A-4 to A-7, Shatavarin I to IV, Sitosterol, Glycosides of quercetin, Stigmasterol, Asparagamine A and Sitosterol 7 (Hayes et al., 2006). The roots of plant are considered to be effective as antispasmodic, appetizer, stomach tonic, aphrodisiac, galactogogue, astringent, anti-diarrheal, antidysenteric, laxative, anti-cancer, antiinflammatory (Tripathi et al., 2007) blood purifier, anti-tubercular, anti-epileptic and also in night blindness, kidney problems and in throat complaints. Satavari is mentioned as medhya-the plants which increase intelligence, promote learning and memory, and as rasayana-the rejuvenator herbs, which improve health by increasing immunity, vitality and resistance, imparting longevity as well as protection against stress. Besides these, Asparagus is a well-known source of the amino acid Asparagine, a non-essential amino acid in humans. Asparagine is a betaamido derivative of aspartic acid and plays an important role in the biosynthesis of glycoproteins and other proteins. The present study was thus taken up to determine chemical composition and overall acceptability of herbal aonla ladoo obtained by utilization satavari roots powder.

\section{Materials and Methods}

Roots of satavari were cleaned, washed and dried in cabinet dryer at $50^{\circ} \mathrm{C}$. Dried roots were ground to fine powder (Plate No. 1) in a hammer mill, packed in LDPE bags and stored at room temperature for use in aonla ladoo. Satavari roots powder (2, 4 and 6\%) was mixed with aonla pulp for preparation of herbal aonla ladoo. Aonla ladoo (control) were prepared by using $1 \mathrm{~kg}$ aonla pulp, $750 \mathrm{~g}$ sugar and $1 \mathrm{~g}$ cardamom powder (small) as per the procedure shown in flow sheet (Fig. 1). On basis of sensory evaluation, optimum quantity of satavari roots powder was standardized for the preparation of herbal aonla ladoo. For processing aonla ladoo, the mixture was cooked till desired consistency was obtained. The product was then cooled, rolled into ladoo and packed in polypropylene (PP) boxes. The freshly prepared herbal aonla ladoo containing satavari powder was analyzed for various chemical characteristics. Total soluble solids (TSS) were estimated at ambient temperature by hand refractometer $(0-32 \%)$ and the values were expressed as percent TSS. Ascorbic acid was analyzed according to AOAC (1990) method. Non- enzymatic browning (NEB) was determined according to the method of Ranganna (2008). Total phenols were analyzed as per the methods given by Amorium et al., (1997), while organoleptic evaluation by using 9 point hedonic scale. The moisture content of herbal aonla ladoo was determined by Dean and Stark method. The 
water activity of processed products was recorded by water activity meter (Labswiftaw, Novasina, Switzerland). The instrument was calibrated with water activity meter calibration humidity salts (11, 58 and 84\%). Sugars were estimated by the method of Hulme and Narain (1931). Total phenols (expressed as tannins) were estimated by the Amorium et al., (1997). Antioxidant activity was measured using stable 2, 2-diphenyl-1-picrylhydrazyl (DPPH) radical as per the method described by Shimada et al., (1992).

\section{Results and Discussion}

\section{Organoleptic quality of herbal aonla ladoo}

The data pertaining to effects of incorporation of various levels of supplements (satavari) on sensory attributes of aonla ladoo variants has been shown in Table 1. Aonla ladoo were evaluated for sensory attributes viz., colour and appearance, taste, texture, mouthfeel and overall acceptability. Mean score for colour and appearance, taste, texture, mouthfeel and overall acceptability of control aonla ladoo were $8.2,8.1,8.0,8.0$ and 8.0, respectively. In herbal aonla ladoo, no significant change in mean score of various sensory attributes was noticed with incorporation of satavari powder upto $4 \%$. However, the mean score for sensory attributes viz., colour and appearance taste, texture, mouth feel and overall acceptability of herbal aonla ladoo containing 6\% satavari powder, respectively was significantly lower thancontrol. Overall acceptability scores indicate that herbal aonla ladoo containing 6\% satavari powder, respectively were "Neither liked nor disliked". Thus, formulations containing 4\% satavari powder were selected for preparation of herbal aonla ladoo.

\section{Chemical constituents of herbal aonla ladoo}

Changes in moisture \%, water activity, total soluble solids (TSS), total sugar, reducing
Sugar, Titratable acidity, ascorbic acid, total phenols, non-enzymatic browning, Antioxidant activity and pectin in herbal aonla ladoo during three months storage period in present study have been presented in Table 2 . The moisture content of herbal aonla ladoo containing $4 \%$ satavari was found decreased significantly during three months storage. This may be due to evaporation of moisture from the samples at room temperature during storage. Singh et al., (2010) reported a decline in moisture content of intermediate moisture baby corn during storage. Singh et al., (2012) also reported decrease in moisture content in aonla supari during 135 days of storage period. Water activity of herbal aonla ladoo ranged from 0.75 to 0.67 during three months of storage. The progressive decrease in $a_{w}$ of herbal aonla ladoo during storage might be due to loss of moisture content from the samples. Ayub and Alam (2002) reported decline in $\mathrm{a}_{\mathrm{w}}$ of dehydrated sweetened guava slices. Singh et al., (2012) also reported decline in water activity of aonla supari during 135 days storage period.

Total soluble solids were found to increase significantly in herbal aonla ladoo during three months storage. This might be due to conversion of polysaccharides into soluble sugars by hydrolysis process and reduction in moisture content of the product during storage. Similar results were reported by Ayub et al., (2005) in sweetened guava slices, Daisy et al., (2007) in aonla preserve, Goyal et al., (2008) in aonla candy, Ram et al., (2011) in aonla bael blended RTS beverage and Choudhary et al., (2012) in aonla nectar. There was a gradual and significant increase in total sugars of herbal aonla ladoo with the advancement of storage period. The increase in level of sugars can be attributed to loss of moisture from the products and hydrolysis of starch and pectin into simple sugars. Similar finding were reported by Ram et al., (2011) in aonla bael blended RTS beverage and 
Choudhary et al., (2012) in aonla nectar, Gaikwad et al., (2013) in aonla ginger RTS beverage and Patel et al., (2013) in aonla murabba. Reducing sugars of herbal aonla ladoo ranged from 28.2to 31.2 during three months of storage. The increase in reducing sugars corresponds to increase in total soluble solid (TSS). Thus, it could be due to moisture loss and inversion of non-reducing into reducing sugars by hydrolysis. Rani and Bhatia (1986) also showed an increase in reducing sugars during 24 weeks storage of Bagughosa preserve, which was ascribed to increased inversion of sugars. Similar results were also reported by Mir and Nath (1993) in fortified mango bar, Sivakumar et al., (2007) in guava toffee, Nagpal and Rajyalakshmi (2009) in bael-citrus fruit blend and Panwar (2014) in IMF aonla segments and aonla candy. Gradual and significant increase in titratable acidity of herbal aonla ladoo was observed during three months storage. The increase in acidity might be due to conversion of sugar into acids (Manivasgan et al., 2006), degradation of polyphenols and conversion of proteins to amino acids. Pectic acid has also been reported to increase the acidity in fruit products; hence, degradation of insoluble pectic substances into soluble pectate might also have contributed towards an increase in acidity of some products.

These results are in accordance with those of Hussain et al., (2004) in osmotically dehydrated banana slices, Kaikadi et al., (2006) in ber candy, Manivasagan et al., (2006) in karonda candy and Nayak et al., (2012) in aonla candy. Ascorbic acid content decreased significantly in herbal aonla ladoo during three months storage period. This loss of ascorbic acid could be attributed to oxidation of ascorbic acid to dehydro-ascorbic acid with passage of time. Similar findings have been confirmed by reduction by Tandon et al., (2003) in aonla candy, Muhammad et al., (2008) in apple jam, Hussainand Shakir (2010) in apricot and apple jam, Bhuiyan
(2012) in fresh hog plum chutney, Choudhary et al., (2012) in aonla syrup, Souad et al., (2012) in watermelon waste jam and Vikram et al., (2012) in aonla herbal jam. The ascorbic acid content was found to decrease more rapidly in the initial stages but the decrease was slow in the later stages with increase in storage period. Similar result was reported by Patel et al., (2013) in aonla murabba during 180 days of storage period. A non-significant decrease in pectin content of herbal aonla ladoo was noticed during first month of storage period. However, decrease in pectin content of herbal aonla ladoo was found significant in later months of storage.

This decrease in pectin content might be due to degradation of pectin into pectic acid during storage. Similar results were reported by Mehta et al., (2005) in galgal peel candy and Patel et al., (2013) in aonla murabba. A significant decrease in total phenols of herbal aonla ladoo was recorded during three months storage. The decrease in total phenols during storage might be due to their condensation into brown pigments (Fennema, 1976). The phenolic acids are oxidized to 0 - semiquinone residuals or 0 -quinone molecules, which are reactive to give brown products of high molecular weight. Decrease in total phenols during storage was also reported by Kannan and Thirumaran (2001) in jamun products (RTS drink, squash, syrup and jam), Kaushik et al., (2002) in bael preserve, Deka et al., (2005) in mango-pineapple based spiced RTS drink, Punam et al., (2009) in bael-mango RTS drink and squash. Non-enzymatic browning increased significantly in herbal aonla ladoo with the advancement in three months storage period. This might be due to condensation of tannins into brown pigments and inversion of non-reducing to reducing sugars, which participated in maillard browning. Browning index of ash gourd candy (Srivastava et al., 2006) and karonda candy (Manivasagan et al., 2006) also increased during storage. 
Plate.1 Flowchart for processing of satavari powder

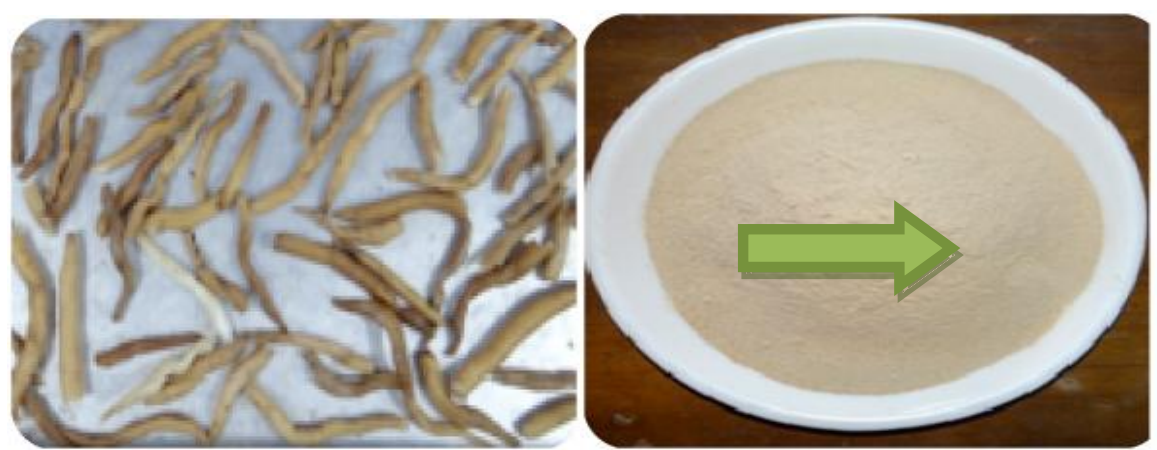

\section{Raw satavari Powder}

Fig.1 Flow sheet for preparation of aonla ladoo

Mature aonla fruits

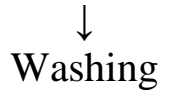

Blanching in $2 \%$ brine solution $+2 \%$ alum solution $+0.2 \%$ KMS solution

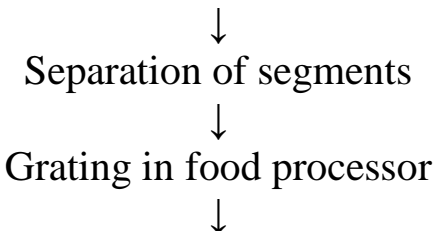

Mixing sugar, cardamom powder and other ingredients to pulp (as per recipes)

Cooking till desired consistency

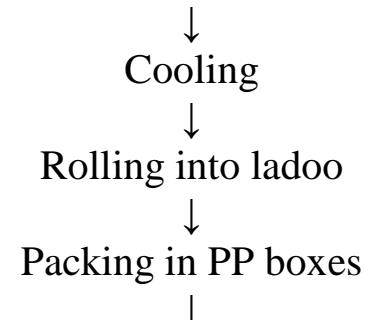

Storage

Table.1 Organoleptic quality of herbal aonla ladoo

\begin{tabular}{|c|c|c|c|c|c|c|}
\hline \multirow{2}{*}{\multicolumn{2}{|c|}{ TREATMENTS (\%) }} & \multicolumn{4}{|c|}{ Characters } & \multirow{2}{*}{$\begin{array}{c}\text { Overall } \\
\text { Acceptability }\end{array}$} \\
\hline & & Colour and & Taste & Texture & Mouth feel & \\
\hline \multirow[t]{5}{*}{ Satavari } & 0 & 8.2 & 8.1 & 8.0 & 8.0 & 8.0 \\
\hline & 2 & 7.8 & 7.7 & 7.7 & 7.7 & 7.7 \\
\hline & 4 & 6.3 & 6.2 & 5.7 & 5.5 & 5.9 \\
\hline & 6 & 6.0 & 5.9 & 5.5 & 5.1 & 5.6 \\
\hline & $\mathrm{CD}$ at $5 \%$ & 0.49 & 0.53 & 0.43 & 0.47 & 0.41 \\
\hline
\end{tabular}


Table.2 Effect of storage period on chemical constituents of herbal aonla ladoo

\begin{tabular}{|c|c|c|c|c|c|}
\hline Herbal aonla ladoo & \multicolumn{3}{|c|}{ Storage period (Months) } & \multirow{2}{*}{ CD at 5\% } \\
\hline Moisture \% & $\mathbf{0}$ & $\mathbf{1}$ & $\mathbf{2}$ & $\mathbf{3}$ & \\
\hline Water activity & 35.3 & 34.4 & 31.6 & 28.2 & 1.1 \\
\hline TSS & 0.75 & 0.74 & 0.72 & 0.67 & 0.03 \\
\hline Total Sugar & 63.3 & 66.4 & 69.1 & 72.7 & 0.34 \\
\hline Reducing Sugar & 52.7 & 53.4 & 53.9 & 54.7 & 0.45 \\
\hline Titratable acidity & 28.2 & 29.7 & 30.6 & 31.2 & 2.7 \\
\hline Ascorbic acid & 1.46 & 1.50 & 1.53 & 1.59 & 0.05 \\
\hline (mg/100g) & 257 & 228 & 201 & 190 & 4.77 \\
\hline Total phenols & 1.99 & 1.89 & 1.79 & 1.62 & 0.07 \\
\hline NEB & 0.13 & 0.17 & 0.23 & 0.30 & 0.01 \\
\hline Antioxidant activity & 58.8 & 48.9 & 39.9 & 32.8 & 1.7 \\
\hline Pectin \% & 0.43 & 0.43 & 0.41 & 0.39 & 0.02 \\
\hline
\end{tabular}

Similar increase in browning index during six months of storage was also reported in IMF aonla segments and aonla candy by Panwar (2014). Antioxidant activity decreased significantly in aonla ladoo variants during three months storage period. Phenolic compounds and ascorbic acid content have been proved to be responsible for the antioxidant activity of aonla fruit (Kumar et al., 2006; Sabu and Kuttan, 2002; Anila and Vijayalakshmi, 2003). This loss in antioxidant activity could be attributed to oxidation or loss of ascorbic acid and phenolic compounds in herbal aonla ladoo with the passage of time. Similar results were reported by Kumari (2014) in rainy and winter season guava fruits during two weeks storage.

It can be concluded from the present investigation that among different levels of supplement satavari (4\%) was found to be the most acceptable formulations for preparation of herbal aonla ladoo. The moisture content (\%), water activity (aw), ascorbic acid, pectin, total phenols and antioxidant activity decreased significantly in herbal aonla ladoo during three months of storage. While TSS, total sugar, reducing sugars, titratable acidity and non-enzymatic browning increased significantly in herbal aonla ladoo during three months of storage. Thus, present study was first in its kind to determine overall acceptability and chemical composition of herbal aonla ladoo obtained from aonla fruits cv. Chakaiya and satavari root powder.

\section{Acknowledgements}

The present work was investigated under the guidance of elite members of advisory committee; Dr. Rakesh Gehlot, Dr. Saleem Siddiqui, Dr. S.K. Sehrawat and Dr. Manju Tonk, Faculty Members at CCS, Haryana Agricultural University (HAU), Hisar, Haryana-125004 for their inexhaustible encouragement and sincere co-operation and HAU for providing funds.

\section{References}

A.O.A.C. (1990). Official Methods of Analysis. Association of Official Analytical Chemists. Washington, D.C. 15th edition.

Amorium, H.V., Dougall, D.K. and Sharp, W.R. (1997). The effect of carbohydrate 
and nitrogen concentrations of phenol synthesis in plant scarlet rose cells grown in tissue culture. Physiologia Plantarum, 39, 91-95.

Anila, L. and Vijayalakshmi, N.R. (2003) Antioxidant action of flavonoids from Mangifera indica and Emblica officinalis in hypercholesterolemic rats. Food Chemistry, 83, 569-574.

Ayub, M. and Alam, S. (2002) Effect of crystalline sucrose on the water activity and overall acceptability of osmotically dehydrated apple slices. Sarhad Journal of Agriculture, 18(1), 99-105.

Ayub, M., Zeb, A. and Ullah, J. (2005) Effect of various sweeteners on chemical composition of guava slices. Sarhad Journal of Agriculture, 21(1), 131-134.

Bhuiyan, M.H.R. (2012) Pickle and Chutney Development from Fresh Hog Plum (Spondiasdulcis). Journal of Environmental Science and Natural Resources, 5(2), 67-72.

Choudhary, M. L., Verma, I.M., Singh, J. and Godara, S.L. (2012) Studies on aonla (Emblica officinalis G.) nectar and biochemical changes with advancement of storage period. Asian Journal of Horticulture, 7(1), 128-132.

Choudhary, M.L., Verma, I.M., Singh, J., Chandra, A. and Godara, S. L. (2012) Storability studies of aonla (Emblicaofficinalis Gaertn.) syrup. Madras Agriculture Journal, 99(4/6), 403-406.

Daisy, Gehlot, R. and Singh, R. (2007).Studies on physico-chemical composition and changes in biochemical constituents of aonla fruits cv. Banarasi during processing into preserve. Haryana Journal of Horticultural Science, 36(3and4), 247248.

Deka, B.C., Sethi, V. and Saikia, A. (2005) Changes in quality of mango-pineapple spiced beverage during storage. Indian Journal of Horticulture, 62(1), 71-75.

Fenemma, O.R. (1976) Principles of Food Science. Part-I. Food Chemistry. Marcel Dekker Inc., New York and Basel, pp.80-81.

Gaikwad, K.K., Singh, S. and Shakya, B.R. (2013) Studies on the development and shelf life of low calorie herbal aonlaginger RTS beverage by using artificial sweeteners. Journal of Food Processing and Technology, 4 (1), 200.

Goyal, R.K., Patil, R.T., Kingsly, A.R.P., Walia, H. and Kumar, P. (2008) Status of post-harvest technology of aonla-A review. American Journal of Food Technology, 3(1), 13-23.

Hayes P.Y., Jahidin A.H., Lehmann, R., Penman, K. and Devoss, J.J. (2006) Structural revision of shatavarins I and IV, the major components from the roots of $A$. racemosus. Tetrahedron Letters, 47(39), 6965-6969.

Hulme, A.C. and Narain, R. 1931. The ferricyanide method for determination of reducing sugars. A modification of Hagedom-Jensen-Hanes technique. Biochemistry Journal, 25(4), 10511061.

Hussain, I. and Shakir, I. (2010) Chemical and organoleptic characteristics of jam prepared from indigenous varieties of apricot and apple. World Journal of Dairy and Food Science, 5(1), 73-78.

Hussain, I., Iqbal, M., Shakir, I. and Ayub, M. (2004) Effect of sucrose and glucose mixture on the quality characteristics of osmotically dehydrated banana slices. Pakistan Journal of Nutrition, 3(5), 282-284.

Kaikadi, M.A., Chavan, U.D. and Adsule, R.N. (2006) Studies on preparation and shelf life of ber candy. Beverage and Food World, 33(8), 49-50.

Kannan, S. and Thirumaran, A.S. (2001) Studies on storage life of jamun 
products. Indian Food Packer, 55(6), 125-127.

Kaushik, R.A., Yamdagni, R. and Dhawan, S.S. (2002) Biochemical changes during storage of Bael preserve. Haryana Journal of Horticultural Sciences, 31(3and4), 194-196.

Kumar, G.S., Nayaka, H., Dharmesh, S.M. and Salimath, P.V. (2006) Free and bound phenolic antioxidants in amla (Emblica officinalis) and turmeric (Curcuma longa). Journal of Food Composition and Analysis, 19, 446-452.

Kumar, S. and Nath, V. (1993) Storage stability of aonla fruits: a comparative study of zero energy cool chamber versus room temperature. Journal of Food Science and Technology, 30(3), 202-203.

Kumari, J. (2014) Study on the combined effect of heat treatment and growth regulators on shelf life of guava (Psidium guajava L.). M.Sc. Thesis, CCS Haryana Agricultural University, Hisar, India.

Manivasagan, S., Kumar, G.S.R. and Joon, M.S. (2006) Qualitative changes in karonda (Carissa carandas Linn.) candy during storage at room temperature. Haryana Journal of Horticultural Sciences, 35(1and2), 1921.

Mehta, A., Ranote, P.S. and Bawa, A.S. (2005) Processing of kandi lemon (Galgal) peel waste candy making. Indian Food Packer, 59(1and2), 67-74.

Mir, M.A. and Nath, N. (1993) Storage changes in fortified mango bars.Journal of Food Science and Technology, 30(4), 279-282.

Muhammad, A., Durrani, Y., Zeb, A., Ayub, M. and Ullah, J. (2008). Development of diet jam from apple grown in swat (nwfp). Sarhad Journal of Agriculture, 24(3), 461-467.
Nagpal, S. and Rajyalakshmi, P. (2009) Quality and storage of RTS beverage from bael and citrus fruit blends. Beverage and Food World, 36(4), 2426.

Nayak, P., Tandon, D.K. and Bhatt, D.K. (2012) Study on changes of nutritional and organoleptic quality of flavored candy prepared from aonla (Emblica officinalis G.) during storage. International Journal of Nutrition Metabolism, 4(7), 100-106.

Panwar, S. (2014) Development of Intermediate Moisture Food (IMF) segments and candy from aonla (Phyllanthus emblica L.). PhD Thesis, CCS Haryana Agricultural University, Hisar, India.

Patel, K.K., Gupta, R. and Kuchi, V.S. (2013) Influence of Pretreatments and Varieties on Biochemical Quality during Aonla (Emblicaofficinalis G.) Murabba Preservation. International Journal of Agriculture, Environment and Biotechnology, 6(4), 633-637.

Patel, K.K., Gupta, R. and Kuchi, V.S. (2013) Influence of Pretreatments and Varieties on Biochemical Quality during Aonla (Emblica officinalis G.) Murabba Preservation. International Journal of Agriculture, Environment and Biotechnology, 6(4), 633-637.

Punam, Gehlot, R., Singh, R.andSiddiqui, S. (2009) Development and evaluation of bael-mango ready-to-serve drink and squash. Haryana Journal of Horticultural Sciences, 38(3), 232-236.

Ram, R.B., Meena, M.L., Sonkar, P., Lata, R. and Upadhyay, A.K. (2011). Standardization and evaluation of blended aonla (Emblicaofficinalis G.) and bael (Aeglemarmelos) RTS beverages. PlantArchives, 11(1), 205208.

Ranganna, S. (2008) Handbook of Analysis and Quality Control for Fruit and 
Vegetable Products. Tata McGraw Hills Publishing Co. Ltd., New Delhi.

Rani, U. and Bhatia, B.S. (1986). Studies on bagugosha and pear for preserves and a ready to eat product. Indian Food Packer, 40(3), 25-31.

Reddy, V., Urooj, A. and Kumar, A. (2005). Evaluation of antioxidant activity of some plant extract and their application in biscuits. Food Chemistry, 90, 317321.

Sabu, M.C. and Kuttan, R. (2002). Antidiabetic activity of medicinal plantsand its relationship with their antioxidant property. Journal of Ethno pharmacology, 81, 155-160.

Singh, J., Koul, R., Bhat, A., Sood, M. and Bandral, J.D. (2012.) Comparative studies on compositional changes in aonla supari (Emblica officinalis) during storage. Annals of Food Science and Technology, 13(1), 19-24.

Singh, M., Dhawan, S.S., Siddiqui, S. and Gehlot, R. (2010) Development of Intermediate Moisture Baby corn. Beverage and Food World, 37(12), 6061.

Sivakumar, K.P., Malathi, D. and Nallakurmbam, B. (2007) Preparation and evaluation of guava toffee.
Beverage and Food World, 34(9), 6870.

Souad, A.M., Jamal, P. and Olorunnisola, K.S. (2012). Effective jam preparations from watermelon waste. International Food Research Journal, 19(4), 15451549.

Srivastava, A.K., Singh, O.P. andSrivastava, P.K. (2006). Development of jaggery based petha (Ash Gourd) candy, its quality evaluation and study on stability under ambient and refrigerated storage. Beverage and Food World, 33(8), 7173.

Tandon, D.K., Yadav, R.C., Sood, S., Kumar, S. and Dikshit, A. (2003) Effect of blanching and lye peeling on the quality of aonla candy. Indian Food Packer 57(6), 147-152.

Tripathi, R.K. and Bhatnager, J.K. (2007) A Comparative study of satavar and its supposed botanical source. Indian Journal of. Pharmaceutical Sciences, 20: 30-40.

Vikram B., Man, B., Narayan, S. and Prasad, V.M. (2012) Effect of dried powder of Tulsi leaf, Ginger and Cardamom addition on Aonla Jam with granulated particles of Cashew. Environment and Ecology, 30 (3A), 635-640.

\section{How to cite this article:}

Jyoti Prabha Bishnoi, Rakesh Gehlot, S. Siddiqui and Isha Kaushik. 2018. Processing and Utilization of Satavari Roots for Preparation of Herbal Aonla ladoo. Int.J.Curr.Microbiol.App.Sci. 7(03): 2698-2706. doi: https://doi.org/10.20546/ijcmas.2018.703.312 